\title{
Uma mirada bibliográfica: revisão das pesquisas empíricas desenvolvidas no Centro Espírita Beneficente União do Vegetal
}

\author{
An Bibliography Outlook: a Review of Empirical Researches Developed at \\ the Centro Espírita Beneficente União do Vegetal
}

\author{
Patrick Walsh' e Emanuel Luz ${ }^{2}$
}

\begin{abstract}
Resumo
Esse texto versará a respeito de uma revisão bibliográfica das pesquisas empíricas desenvolvidas no Centro Espírita Beneficente União do Vegetal (CEBUDV), também conhecida como União do Vegetal ou simplesmente UDV. Nos rituais desta religião se utiliza um sacramento, denominado Hoasca ou Vegetal, e conhecido também pelo nome Ayahuasca no campo acadêmico e nos meios de comunicação. 0 chá é feito a partir da maceração do cipó Mariri (Banisteriopsiscaapi) e das folhas da Chacrona (Psychotriaviridis), tratando-se de um psicoativo que é utilizado nos rituais desta religião para efeito de concentração mental e com o objetivo de desenvolvimento das virtudes espirituais, morais e intelectuais. Para tal empreendimento, privilegiou-se as dissertações de mestrado e teses de doutorado defendidas entre os anos de 1995 e 2016. Esse recorte histórico tem o objetivo de situar e apresentar para os futuros pesquisadores desse tema os recortes, relações e interfaces investigadas até o período estabelecido. Por outro lado, apresentaremos os nossos comentários e impressões a partir da leitura dos textos que embasaram a elaboração desse artigo.
\end{abstract}

Palavras-chave: CEBUDV, Pesquisas Empíricas, Revisão bibliográfica, Ayahuasca, Hoasca.

\begin{abstract}
This text will deal with a review of the bibliographic produced in the sciences, based on empirical researches developed at the Centro Espírita Beneficente União do Vegetal (CEBUDV), also know as União do Vegetal or simply UDV. In the rituals of this religion a sacrament, called Hoasca or Vegetal, and also known by the name Ayahuasca in the academic field and in the media. The tea is made from the maceration of Mariri (Banisteriopsiscaapi) and leaves of Chacrona (Psychotriaviridis), a psychoactive that is used in the rituals of this religion for the purpose of mental concentration and with the objective of developing the spiritual, moral and intellectual virtues. For this project, the master's dissertations and doctoral theses defended between the years 1995 and 2016 were privileged. This historical clipping has the objective of situating and presenting to the future researchers of this theme, the cuts, relations, and interfaces investigated until this established period. On the other hand, we will present our comments and impressions from the reading of the texts that supported the preparation of this article.
\end{abstract}

Key-words: CEBUDV, Empirical Research, Literature Review, Ayahuasca

\footnotetext{
1 Doutor em Sociologia pela Universidade de Brasília. Defendeu a sua tese de doutorado em dezembro de 2017. E-mail: patrick_walsh25@hotmail.com Cidade: Brasília.

2 Doutorando em Ciências Humanas, com ênfase em Antropologia Cultural, pelo PPGSA/IFCS/UFRJ. E-mail: emanuelluz59@gmail.com Cidade: Rio de Janeiro.
} 


\section{Introdução}

Esse texto tem o objetivo de apresentar uma revisão bibliográfica das pesquisas que foram conduzidas por pesquisadores de diversos programas de pós-graduação, de diversas Universidades,a respeito do Centro Espírita Beneficente União do Vegetal (CEBUDV $\left.{ }^{3}\right)$, também conhecido como União do Vegetal ou simplesmente UDV. Um dos aspectos que demonstraremos, com base nos trabalhos revisados, é que há uma pluralidade expressiva de pessoas que compõem essa religião do sentirt, com as suas concepções ontológicas e motivações diversas para as adesões, fixações e permanências, diferentes histórias de vida, itinerações religiosas, fluxos, origens e flutuações de classes sociais, politicas, interesses pessoais, acadêmicos e intelectuais, bem como de outras variantes socioantropológicas que nos permitem apresentar algunsdos diversos aspectos e relações possiveis com as teorias sociais clássicas e contemporâneas. Essas distintas relações teóricas, com esse contexto empírico, serão demonstradas através dos diálogos que iremos desenvolver com a bibliografia que será apresentada ao longo desse texto.

A partir do cenário social de expansão institucional do CEBUDV ao redor do globo, de pluralidades e singularidades das adesões e ressonâncias dos devires transformativos narrados pelos seus diversos sócios, aguçou-se de modo gradativo, o interesse por esse tema na mídia, na sociedade civil mundial, bem como nos diversos programas de pós-graduação das inúmeras universidades nacionais e internacionais.

\footnotetext{
3 Em pesquisas acadêmicas geralmente se referem ao CEBUDV como União do Vegetal ou simplesmente UDV. Neste artigo optamos por nos referir a esta religião como CEBUDV porque é a forma a qual a instituição se dirige ao público externo e as autoridades governamentais em suas publicações oficiais. Devido à vasta produção bibliográfica a respeito das religiões ayahuasqueiras (Santo Daime, Barquinha e o Centro Espírita Beneficente União do Vegetal) nos últimos anos, optamos por estabelecer uma delimitação temática nesse campo religioso ayahuasqueiro. Assim, nesse artigo, o nosso diálogo será dirigido para os trabalhos que foram produzidos a respeito do CEBUDV. Desse modo, embora tenhamos conhecimento das produções textuais dos membros do Núcleo de Estudos Interdisciplinares sobre Psicoativos (NEIP), cujos textos estão disponíveis na página virtual desse grupo de pesquisa, nós não nos dirigiremos a essa bibliografia. Pois, em sua maioria, são textos produzidos a partir de pesquisas empíricas que foram conduzidas no Santo Daime (em suas diversas linhas), bem como na Barquinha. Ressaltamos tratar-se de um importante grupo de pesquisa, com referências bibliográficas imprescindiveis para o mapeamento do campo ayahuasqueiro.

${ }^{4}$ Termo cunhado pelo jornalista Flâminio Araripe, na reportagem intitulada: "União do Vegetal: a oasca e a religião do sentir". Essa publicação foi feita na edição de junho de 1981, na Revista Planeta.
} 
Nesse sentido, diversas são as áreas (antropologia, sociologia, ciência da religião, geografia, farmacologia, psiquiatria, psicologia, história) e os pesquisadores que passaram a se interessar por pesquisar os diversos temas que gravitam no bojo desse fenômeno religioso, de gênesis amazônica e brasileira, que tem no uso da Hoasca $^{5}$ o seu sacramento, associado à vida comunitária e aos ensinamentos de José Gabriel da Costa, os seus aportes e referenciais institucionais basilares.

O Centro Espírita Beneficente União do Vegetal teve a sua criação no dia 22 de julho de 1961, por José Gabriel da Costa junto a sua esposa, Raimunda Ferreira da Costa, aos seus filhos e um pequeno grupo de pessoas. Esse marco temporal é significativo para os sócios desse Centro Espírita. A localização geográfica desse acontecimento é o seringal Sunta, na fronteira do Brasil com a Bolivia, do lado boliviano, na altura do Estado do Acre. O ambiente hostil e caótico desse seringal amazônico foi o berçode uma religião de fundamentação cristã e reencarnacionista,que tem como principal propósitocontribuir para o desenvolvimento espiritual do ser humano.Nesse período histórico, de gênesis desse Centro, o uso do chá era disseminado entre os seringueiros, mas nem sempre era usado com o fim de concentração mental e de desenvolvimento espiritual6. Nesse contexto, Mestre

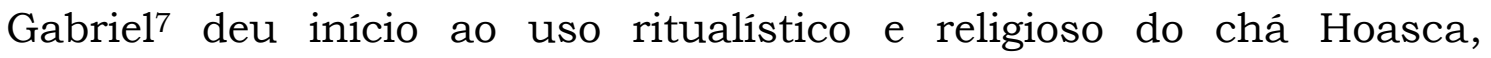
adotando uma forma de trabalho espiritual que rapidamente ganhou o

\footnotetext{
5 A UDV tem como sacramento um chá, denominado Hoasca ou Vegetal, feito a partir de duas plantas, o cipó Mariri (Banisteriopsiscaapi) e a folha do arbusto Chacrona (Psychotriaviridis). Estes vegetais são sinérgicos, ou seja, tem um efeito cooperativo dos seus agentes sobre o organismo. No Mariri tem substâncias químicas chamadas betacarbolinas (harmina, harmalina e tetrahidroarmina) que são inibidoras da monoaminoxidase (MAO), já na folha da Chacrona encontramos as moléculas de Dimetiltriptamina (DMT), que é a principal substância responsável pelos efeitos psicoativos do chá. Para se ter os efeitos desejados no organismo humano, uma planta necessita da ação combinada com a outra, é a união do Mariri com a Chacrona que proporciona entrar em Estado Ampliado de Consciência (EAC) ${ }^{5}$. Por que é necessário essa sinergia entre essas duas plantas? No figado e no intestino humano existem as monoaminoxidases (MAOs), estas substâncias degradam a DMT quando esta é ingerida oralmente. Portanto, a ação das betacarbolinas contidas no Mariri resultam em inibição das MAOs contidas no figado e no intestino, proporcionando que a DMT (Dimetiltriptamina) contida na Chacrona entre na corrente sanguínea e chegue até a barreira sanguínea do cérebro ativando a glândula pineal e proporcionando à pessoa o EAC (WALSH NETTO, 2018).

6 Naquele período já existiam as doutrinas do Daime e da Barquinha em Rio Branco-AC. No entanto, nos seringais onde Mestre Gabriel bebeu o chá pela primeira vez essas doutrinas não haviam sido difundidas. Os seringueiros conheceram e aprenderam a fazer o chá com os índios da região, mas não seguiam o uso ritualístico. Muitos deles se referiam aos efeitos do chá como "cinema de índio", em alusão às visões provocadas pelos efeitos do chá.

7 José Gabriel da Costa é chamado no CEBUDV de Mestre Gabriel.
} 
respeito e angariou discípulos que queriam aprender com aquele senhor os ensinos "sagrados" da Hoasca8.

Na passagem do ano de 1964 para o ano de 1965, José Gabriel da Costa chegou com a sua família em Porto Velho-RO, dando início, nessa cidade, a uma nova fase do desenvolvimento dessa religião. Em razão das perseguições policiais, que consideravam o chá um entorpecente, Mestre Gabriel e seus discipulos procuraram organizar institucionalmente essa religião, com a criação da Associação Beneficente União do Vegetal e, em seguida, devido à intensificação dessa perseguição policial, se deu a criação do Centro Espírita Beneficente União do Vegetal (CEBUDV), no ano de 19719. Em 24 de setembro de 1971, o Mestre Gabriel fez a passagem ${ }^{10}$, na cidade de Brasília-DF. A partir daquele momento, os primeiros Mestres, Conselheiras e Conselheiros, junto aos seus primeiros discípulos, deram continuidade ao trabalho de crescimento e expansão desse Centro Espírita no Brasil e no exterior ${ }^{11}$.

Em continuidade ao trabalho iniciado por Mestre Gabriel pelos seus primeiros discípulos, podemos apresentar um crescimento numérico considerável de sócios no CEBUDV, desde a sua chegada nos contextos urbanos, no início da década de $1970^{12}$. Podemos comprovar

\footnotetext{
8OCEBUDV tem como sacramento um chá, denominado Hoasca ou Vegetal, feito a partir de duas plantas, o cipó Mariri (Banisteriopsiscaapi) e a folha do arbusto, Chacrona (Psychotriaviridis). Estes vegetais são sinérgicos, ou seja, tem um efeito cooperativo sobre o organismo. Em outros contextos este mesmo chá é conhecido pelo nome Ayahuasca, Daime, Mariri, Yagé etc.

${ }^{9}$ A renomeação de "Associação" para "Centro Espírita" se deu em decorrência da necessidade de utilizar uma clara definição, no seu estatuto, de que se tratava de uma religião de fundamentação cristã- reencarnacionista. O Mestre Gabriel e os sócios da UDV se referiam nas atividades cotidianas da UDV como uma religião espírita. Esta questão é amplamente debatida no capítulo 4 da tese de Patrick Walsh Netto, ver referência na bibliografia deste artigo.

10 "Fazer a passagem" é uma categoria nativa que significa dizer que a matéria, o corpo, repousou. Para o espiritismo, o espírito é eterno, não morre. Mestre Gabriel fez a passagem no dia 24 de setembro de 1971 na cidade de Brasília-DF.

11 O CEBUDV é uma religião hierárquica e o acesso a cosmologia desta religião é dada de acordo com a ascensão aos graus hierárquicos. Em relação à hierarquia, o maior grau é ocupado pelo Mestre Geral Representante (MGR), seguido por: Mestre Assistente Geral (MAG), Mestre Central (MC), Mestre Assistente Central (MAC), Mestre Representante (MR), Mestre Assistente (MA), Quadro de Mestres (QM), Corpo do Conselho (CDC), Corpo Instrutivo (CI) e Quadro de sócios (QS). O Mestre Geral Representante é a autoridade máxima do CEBUDV, responsável pela supervisão do trabalho espiritual e administrativo no Brasil e no exterior. A ascensão e permanência nos graus estão ligados à conduta do indivíduo, já que é necessário decoro e adequação ao lugar que a pessoa está ocupando.

12 Mestre Gabriel criou uma espécie de gestão participativa, em que tanto a organização administrativa, quanto o trabalho espiritual é pautado no voluntariado. Desde o princípio
} 
essa afirmação através da seguinte comparação: a UDVpassou de um número aquém de duzentas pessoas em dois Núcleos ${ }^{13}$, situados em Porto Velho e Manaus, na década de 1970, para mais de vinte mil sócios alocados em mais de duzentos Núcleos e distribuições autorizadas de Vegetal em todos os Estados do Brasil, EUA, Canadá,Reino Unido, Portugal, Espanha, Suíça, Holanda, Itália, Austrália e Peru (201814).

Após essa breve apresentação do Centro Espírita Beneficente União do Vegetal, iniciaremos, a partir de agora, a descrição e o diálogo com as dissertações de mestrado e teses de doutorado, defendidas e publicadas nas diversas áreas que tiveram o CEBUDV como tema de pesquisa. O nosso objetivo será o de apresentar as principais linhas de pesquisa, debates, vertentes e contribuições que esses trabalhos ofereceram para a comunidade científica, bem como estabeleceremos alguns comentários e ponderações.

\section{As Pesquisas Empíricas na UDV: a multiplicidade dos saberes}

Uma das pesquisas pioneiras, na esteira explicativa da adesão ao CEBUDV no contexto das urbes, é a dissertação de mestrado em Ciências da Religião de Andrade (1995). O objetivo dessa pesquisa foi o de investigar a filiação a esta religião nos centros urbanos, especificamente, em São Paulo. O título desse trabalho é "A religiosidade cabocla e o fenômeno do chá", que segundo esse autor tem nos seringueiros e caboclos, os atores centrais do delineamento dos seus "sistemas de crença”. A pesquisa foi norteada a responder: "como que esta religião que originariamente atendia a seringueiros vem recebendo grande aceitação pela classe média e urbana, e pelos intelectuais"? Em outras palavras, "o que há nela que cativa a estes

dividiu responsabilidades entre os primeiros sócios, de modo que pudessem dar continuidade aos trabalhos quando ele fizesse a passagem. O voluntariado é uma marca indelével do CEBUDV, que traz um forte traço igualitário, já que todos são corresponsáveis pela obra. Por este motivo os nativos do CEBUDV dizem que são sócios desta religião e não adeptos.

13 Núcleo é o nome dado ao espaço onde abrigam os sócios da UDV para o exercício do seu trabalho espiritual, seja através de sessões, seja através do preparo do Vegetal ou de outras atividades. Os núcleos têm também estruturas necessárias para o desenvolvimento do plantio do Mariri e da Chacrona, atividades relacionadas a conservação ambiental e a educação de crianças e adultos.

14Dados oficiais fornecidos em abril de 2018 pelo escritório da Diretoria Geral do CEBUDV. 
segmentos urbanos"? (ANDRADE, 1995, p. 34). A resposta dada pelo autor é a de que esse crescimento no número de seguidores no cenário das metrópoles brasileiras deve-se aos "componentes de seu sistema de crença se encaixarem exatamente com as aspirações dessa classe social". Essas aspirações seriam, segundo ele, a ascensão ao topo da pirâmide social, cuja reverberação dá-se na busca por ascensão aos pontos hierárquicos mais altos da organização. Aos homens o lugar de Mestre. Às mulheres o de Conselheiras. Essa correlação, apresentada por Andrade (1995), centrou-se na busca por status e ascensão social. Os dados dessa pesquisa apresentaram que $7 \%$ dos filiados são de classe baixa; 93\% de classe média. Quanto à escolaridade, 29\% tem $1^{\circ}$ grau completo; $17,1 \%$ tem o $2^{\circ}$ grau completo; $80 \%$ possuem nível superior completo; e, ainda, 21,4\% dos que possuem nível superior completo são pós-graduados. Definiu-se o perfil socioeconômico em uma "Classe média Culta" (ANDRADE, 1995, p. 175). Esses números e estatísticas são apresentados nesses termos pelo autor. Entretanto, esse perfil que é traçado pelo autor vem sendo contestado por pesquisas posteriores, já que o trabalho de Andrade criou uma imagem estereotipada do perfil socioeconômico dos sócios do CEBUDV, bem como das motivações que levaram muitas pessoas a aderirem e seguirem nessa religião. Resumir estas adesões a "aspirações de classe social" é uma miopia em relação à busca de aspirações espirituais de caráter universal que uma significativa parcela dos sócios expressa em suas narrativas e justificativas para as suas adesões a UDV.

Essa pesquisa citada inspirou-se, entre outros aspectos, no artigo escrito por Henman (1986), que lança mão de duas hipóteses de trabalho a respeito do perfil social dos membros da UDV. A primeira, que os sócios seriam fundamentalmente de classe média. A segunda, que em grande medida os sócios desse Centro, da "segunda fase", oriundos dos centros urbanos, teriam utilizado "drogas" antes da adesão à instituição:

Sin embargo, en una segunda fase, muchos de los adherentes eran jóvenes profesionales de clase media que bien pudieron haber tenido experiencias previas con otras drogas; en especial, 
con la mariguana y los alucinógenos ilegales (LSD, mescalina y silocibina). (HENMAN, 1986, p. 221).

Para Andrade (1995), haveria equívocos na afirmação de que os sócios da UDV teriam feito uso de "drogas" antes da adesão a essa "seita15". Para contrapor-se criticamente a Henman (1986), ele aplicou questionários com os sócios da UDV do Núcleo São João Batista (São Paulo/SP). Os dados que são apresentados nessa pesquisa referentes aos usos de substâncias psicoativas dos sócios desse Núcleo antes da associação a UDV, apontam que apenas $8 \%$ dos pesquisados consumiam substâncias ilícitas no período que antecedeu a chegada a essa religião, 56\% teriam consumido álcool e tabaco antes de se associarem ao Centro; 36\% não faziam uso dessas "drogas" citadas quando chegaram à "religião do sentir". Para Andrade (1995), Henman (1986) havia se equivocado quanto à hipótese referente ao uso de "drogas" dos sócios antes de conhecerem a UDV. O que veremos mais na frente, com a pesquisa de Ricciardi (2008), cujo trabalho de campo ocorreu em Salvador (BA), também com Souza (2010), que pesquisou no Maranhão (MA), e com Melo (2011), que fez o seu trabalho de campo em Brasília (DF), são evidências empíricas que apontam para um histórico de usos de "drogas" de um percentual pequeno, mas significativo dos sócios do Centro, em diversos Estados Brasileiros, que são recebidos e integrados na dinâmica cotidiana dessa comunidade religiosa.

É importante destacar que ter feito uso de "drogas" antes da adesão à UDV não significa que a motivação para adesão religiosa se deu com o propósito de utilização da Hoasca como "droga", pois diversas são as pesquisas que demonstram o histórico de uso de substâncias psicoativas antes da filiação religiosa ao Kardecismo, Protestantismo, Pentecostalismo e Catolicismo (SANCHEZ, 2009). Pelo contrário, esse dado aponta que a adesão à UDV tem influenciado diversas pessoas a abandonaremos usos de psicoativos lícitos (cigarro e

\footnotetext{
${ }^{15}$ Andrade chama a UDV de seita. A instituição autodenomina-se como religião. Manteremos a qualificação nativa de religião. Quando o líder religioso e criador da União do Vegetal, José Gabriel da Costa, foi perguntado a respeito de ter criado uma seita, disse nessa direção, nós somos uma seita, "a-seita-todo mundo". Ou seja, no sentido de que 'aceita' a todos aqueles que quiserem conhecê-la.
} 
bebidas alcoólicas) e ilícitos (maconha, cocaina, crack, entre outras) através da prática espírita hoasqueira, com as suas especificidades e particularidades, assim como ocorre com os outros segmentos religiosos que foram exemplificados. Além do mais, em pesquisas mais recentes, com uma maior amostragem de sócios, demonstrou-se que somente um pequeno número de sócios do CEBUDV, em torno de 12\%, chegam a esta religião apresentando estas características (WALSH NETTO, 2018). Apresenta-se assim, um agenciamento semelhante por parte dos indivíduos nas diversas direções religiosas que são adotadas.

Com o objetivo de elucidar esse perfil social que é descrito por Andrade (1995), Brissac (1999) propôs em sua dissertação de mestrado, por um lado, delinear alguns dos marcadores socioeconômicos dos sócios do Núcleo Alto das Cordilheiras (Campinas /SP). Quanto ao estado civil, 53\% dos membros são casados, sendo que desses, 90\% tem seus cônjuges sócios do mesmo núcleo; 22\% são divorciados; $25 \%$ são solteiros. Quanto à escolaridade, o percentual é de $78 \%$ com nivel superior completo; $1 \%$ com $1^{\circ}$ grau completo; $7 \%$ com mestrado; $18 \%$ com doutorado. Quanto à classe social, 86\% se definem como classe média. Segundo esse autor, entre os primeiros sócios do CEBUDV em São Paulo, predominava uma visão de mundo oriunda do movimento da contracultura decorrente da década de 1970. Em grande parte, segundo ele descreve, "eram usuários de drogas" que usavam o LSD com o propósito de autoconhecimento. Eram motivados, sobretudo, por estilos de vida alternativos no bojo de suas concepções de mundo (BRISSAC, 1999, p. 87). Essa perspectiva destoa da hipótese defendida por Andrade (1995). Ao mesmo tempo, apresenta outros aspectos da associação a UDV nos centros urbanos.

Entrementes, podemos observar que os marcadores socioeconômicos dos sócios da UDV que foram pesquisados por Andrade (1995) e Brissac (1999), no contexto urbano de São Paulo, evidenciam-se similares. Uma classe média intelectualizada. Entretanto, em nossa compreensão, estes dados precisam ser melhor verificados, visto que pesquisas estatísticas feitas em outras regiões do país, e com 
uma amostragem maior do que as pesquisas supracitadas, apresentaram resultados bem diferentes e, em alguns casos, até mesmo contrários aos apresentados por estes dois autores (WALSH NETTO, 2018). O que nos leva a concluir que os dados apresentados por estes autores citados ficam mais próximos de uma realidade local e específica destes núcleos que estão localizados em São Paulo - SP.

Por outro lado, a dissertação de mestrado de Brissac (1999) dirigiu-se para descrever a trajetória de vida de José Gabriel da Costa, “o menino de Coração de Maria” (p. 58), bem como para desenvolver um esquema triádico de explicação da UDV: o modelo organizacional, a narrativa histórica e a experiência simbólica. Essa pesquisa foi conduzida através de uma etnografia, na qual o autor formulou do seguinte modo o seu objetivo: "buscarei falar da Estrela do Norte, a partir do modo como as retinas do Sul captam a luz que ela irradia" (BRISSAC, 1999, p. 10).

No início de seu contato com o CEBUDV, Brissac descreve que tinha o propósito de investigar a 'cosmologia' e a 'metafísica' da instituição. Esse objetivo mostrou-se, pouco a pouco, inviável, segundo o autor, pois percebera a existência de um interdito a respeito da divulgação dos princípios doutrinários fora da comunidade ritual. Ou, em outras palavras, a compreensão de que alógica das relações nesse contexto é fundamentada em uma economia simbólica (BRISSAC, 1999, p. 14). A partir daí, limitou-se a escrever a respeito da doutrina divina que é publicada em livros pela instituição e no jornal de circulação interna, o 'Alto Falante'.

A pesquisa de Labigalini (1998), embora tenha partido do referencial teórico da Saúde Mental, desenvolveu-se por meio de uma proposta que visava transversalizar os saberes, com uma metodologia qualitativa, descrição etnográfica e observação participante. O objetivo dessa dissertação de mestrado endossa essa perspectiva de percorrer pelos diversos saberes para investigar os 'significados' e os 'processos' 'culturais' relacionados à dependência ao álcool antes da associação a 
UDV de quatro indivíduos. A pesquisa de campo foi desenvolvida em Araçariguana-SP.

Os resultados descritos por Labigalini (1998) apontam que os pesquisados não apresentavam diagnósticos psiquiátricos antes ou no momento da entrevista, bem como, poucos meses após o contato com a UDV os alcoolistas abandonaram o uso de qualquer tipo de bebida alcóolica. As características desse processo de "cura do estado psicopatológico decorrente do abuso de álcool" foram sistematizadas em três valências: 1) estados de consciência vivenciados nas experiências com a Ayahuasca; 2) inserção em um novo grupo social; 3) ausência de transferência da compulsão do uso abusivo do álcool para o uso da Ayahuasca e a filiação religiosa. Anulou-se, para ele, a possibilidade de qualquer compulsão pelo uso da Ayahuasca. Ou, a mudança de uma dependência por outra (LABIGALINI, 1998, p. 81)16.

No mesmo campo, da psicopatologia e da saúde mental, bem como em uma perspectiva dialógica entre os diversos campos dos saberes, Barbosa (2001) investigou através do método fenomenológico, os estados de consciência induzidos pela ingestão ritualizada da Ayahuasca no Santo Daime e na União do Vegetal em São Paulo. Os estados alterados de consciência $\left(\mathrm{EAC}^{17}\right)$ qualificaram-se em mudanças radicais no funcionamento ordinário mental de cada um dos sujeitos da experiência (TART, 1972). Também nomeado de Estados Não-Ordinários de Consciência (ENOC) (MIKOSZ, 2009).

O objetivo principal da pesquisa de Barbosa (2001) foi o de desenvolver um breve follow-up dos estados de consciência de indivíduos que tiveram o primeiro contato com Ayahuasca. O que ele chamou de T1: vivências no estado de consciência habitual; T2: as vivências nos estados de consciência induzido pela ingestão da ayahuasca; T3: as vivências no retorno ao estado de consciência

\footnotetext{
16Estamos respeitando a escolha de Labigalini de nomear o chá de Ayahuasca na sua pesquisa de mestrado.

17Atualmente, está sendo utilizada a expressão Estado Ampliado de Consciência (EAC), pois essa é desprovida de juízo de valor. Essa expressão foi cunhada pelo micólogo, Robert Gordon Wasson, que acreditava que a linguagem mais adequada para se referir às experiências com os psicoativos deveriam ser mais próximas da realidade e menos carregadas de termos patológicos.
} 
ordinária. Para investigar os estados alterados de consciência (EAC), esse autor aplicou um roteiro que explorava as seguintes variáveis: afetivas, pensamentos, senso de identidade, exterocepção, interocepção, senso espaço-temporal, volição. O roteiro de entrevista para investigar o retorno (EAC) deu-se através de questões a respeito do ambiente familiar e profissional, relacionamentos pessoais diversos, com relação a si próprio e a eventualidades cotidianas (BARBOSA, 2001, p. 14).

Como resultados dessa pesquisa estão os padrões vivenciais de "serenidade e o poder". A "serenidade" "qualificou-se por um silenciamento, tranquilização e mitigação de padrões litigiosos". O "poder" caracterizou-se por um tônus diacrítico "numinoso", contactado em uma instância ascendente (BARBOSA, 2001, p. 256), cujos sentimentos apresentam-se como fundantes dos processos cognitivos nos 'EACs' (p. 257). O follow-up entre o ENC e o ENC' demonstrou haver quedas drásticas em sintomas psiquiátricos; melhoria geral nos estados emocionais; combinações da sinergia "serenidade-poder" sugeridos nos âmbitos do setting ritual. Entretanto, essas mudanças não se mostraram permanentes, mas como resquícios das experiências dos EACs. Essa evidência foi mensurada pelo nível da percepção das melhorias em relação aos distanciamentos temporais das experiências em estado expandido de consciência (BARBOSA, 2001, p. 258).

Com o objetivo de seguir nessa linha investigativa da sua dissertação de mestrado, Barbosa (2008) propôs, em sua tese de doutorado, aconsecução de um follow-up de seis meses em três tempos: 1) uma avaliação dois dias antes da primeira experiência com o psicodélico'18; 2) uma avaliação na semana posterior à participação no ritual; 3) uma avaliação de seis meses após a primeira. Essa terceira fase foi acrescida ao follow-up de Barbosa de (2008) e diferencia-o do follow-up de Barbosa (2001). Segundo o autor, algumas questões haviam ficado em aberto em sua dissertação de mestrado, o que fez com que almejasse trazê-las à luz: 1) "quão profundas ou superficiais seriam

\footnotetext{
${ }^{18}$ Quando nativos e autoridades do CEBUDV se referem aos aspectos farmacológicos do chá Hoasca o nomeiam de psicoativo por considerarem esta nomenclatura mais neutra em relação, por exemplo, a psicodélico e enteógeno.
} 
as mudanças afetivas e/ou comportamentais decorrentes do uso da ayahuasca"; 2) são duradouras ou específicas àqueles momentos da avaliação; 3) os efeitos relacionam-se à repetição ritual; 4) "como se inscreveria o uso ritual da ayahuasca nos itinerários terapêuticos e religiosos dos sujeitos?” (BARBOSA, 2008. p. 18).

No desenvolvimento da pesquisa de doutorado, Barbosa (2008) recrutou alguns membros do Santo Daime (dois templos) e da UDV em São Paulo (um núcleo) e em Campinas (dois núcleos). A coleta dos dados e aplicação do follow-up utilizou-se de três instrumentos: 1) Clinical Interview Schedule-RevisedEdition (CIS - R) que através de uma entrevista estruturada detecta a ocorrência e a intensidade de sintomas psicopatológicos menores; 2) Medical OutcomesStudy 36 Itemsn ShortForm Health Survey (SF-36), esse instrumento tem como propósito avaliar a qualidade de vida; 3) Temperament and CharacterInventory 125 Items(TCI - 125) com foco nos temperamentos dos sujeitos. Na dimensão qualitativa utilizou-se das entrevistas semiestruturadas com base no método fenomenológico e cujo objetivo era o de cotejar esses dados à perspectiva antropológica. Os resultados da amostra indicam que $1 / 5$ dos pesquisados julgou que outras terapias ofereceram maior eficácia do que o uso da ayahuasca e que a regularidade dos usos rituais da Hoasca pode ser benéfica. $\mathrm{Na}$ perspectiva dos pesquisados essas experiências foram significativas e cotejadas à luz de seus itinerários religiosos e terapêuticos. Os resultados quantitativos do SF36 entre o T0 e o T2 do grupo da UDV foram de significativa diminuição de dor corporal (BARBOSA, 2008).

O "numinoso", um dos resultados da pesquisa de Barbosa (2001), obteve centralidade temática em Carvalho (2005). A dissertação de mestrado da autora teve inspiração fenomenológica com o propósito de captar as narrativas dos agentes da "demanda numinosa". Na pesquisa de campo, utilizou-se de entrevistas semiestruturadas, histórias de vida, observação participante e descrição etnográfica. O "campo" de pesquisa desenvolveu-se no Núcleo Pupuramanta, situado no Rio de Janeiro-RJ. As proposições teóricas de W. James, R. Otto e C. G. Jung 
foram as bases de sustentação teórica do trabalho. As questões que nortearam a investigação foram centradas no sentimento do sagrado ou, mais especificamente, na demanda numinosa. Essa questão foi desdobrada na ênfase das experiências íntimas com o superior; no desenvolvimento do processo de individuação; na influência das experiências numinosas, bem como na visão de mundo daqueles que bebem a Hoasca.

Para Otto (2005), as vivências religiosas são inviáveis de serem descritas através da racionalidade cartesiana, pois impõe cesuras aos sentimentos experienciais. Com o propósito de oferecer aquisição qualitativa à exegese fenomênica experiencial do sagrado, esse autor argumenta para a necessidade de um termo substitutivo dessa noção de "sagrado". Segundo o referido autor, essa racionalidade implicaria em uma perda da compreensão da experiência religiosa e do contato místico com o 'sagrado', em primeira pessoa: o 'eu' e o 'superior'. Propõe, então, que ao invés da noção de 'sagrado' seja utilizado o conceito de numinoso, cuja ênfase visa dirigir-se para o sentimento experiencial. Segundo Carvalho, a partir da leitura e influência desse referencial teórico citado, no CEBUDV é visível a percepção de três distintas concepções a respeito desse sentimento experiencial que não são contraditórias entre si, mas sim complementares: "experiência original" James, (2002); "experiência numinosa" Otto (2005); "experiência imediata” Jung (2002).

O mysteriumtremendum que está contido no "numinoso" é invariavelmente irreprodutivel em sua magnitude. Carvalho (2005) destacou os fios dessa noção com o propósito de arregimentá-los aos sentimentos místicos que são experienciados após a ingestão da Hoasca. O primeiro desses elementos é o mysterium, apreensivel exclusivamente pelo sentimento. O segundo é o tremendum, ou a humildade religiosa. A sensação de sentir-se pequeno diante do ser ascendente superior. Segundo Carvalho (2005) "o tremedum, o majestas e a orgêrepresentam aspectos positivos presentes no numinoso e são 
manifestos através dos sentimentos chamados de mysteriumtremendum" (CARVALHO, 2005, p, 57).

Um dos resultados da pesquisa de Carvalho (2005) é que alguns dentre os sócios da UDV agenciam a psicoterapia simultaneamente à experiência religiosa. Mas, segundo ela, o que há de mais relevante entre os resultados da pesquisa é que a demanda numinosa apresentou-se como uma possibilidade do processo de individuação. Esse processo, dado através das 'terapias' ou dos 'caminhos religiosos', podem desembocar na promoção de outro fenômeno, a unificação da personalidade do agente. A partir daí, segundo essa autora, "as decisões tenderão a estar em consonância com os seus anseios mais profundos, caminhando rumo à realização de sua personalidade" (CARVALHO, 2005, p. 138). Nas palavras de Carvalho (2005), "estas duas categorias (religião e psicoterapia) se interpõem no universo de um portador de demanda numinosa [...] que costuma atribuir um significado espiritual mesmo para os problemas de ordem psicológica" (CARVALHO, 2005, p. 140). Com essa correlação estabelecida, Carvalho nos indica que há uma relevância na delimitação mais precisa quanto ao que seja um problema espiritual e um problema psicológico (CARVALHO, 2005).

Nessa interrelação e busca resolutiva dos seus problemas espirituais, bem como dos seus problemas psicológicos, inserimos as necessárias transformações pessoais que são reivindicadas nesses distintos regimes de enunciação. Nesse sentido, Fernandes (2011), que teve como lócus empírico o Núcleo Menino Deus (Manaus/AM), realizou uma descrição etnográfica da União do Vegetal e dos sentidos das suas transformações pessoais. A perspectiva teórica de Belzen (2010), da psicologia cultural, alinhada à proposta interpretativa da cultura de Geertz, é o marco teórico referencial acionado por esse pesquisador. Segundo Fernandes (2011), a sua pesquisa é diferente das propostas anteriores, na área de psicologia, pois em sua maioria enfatizaram apenas os efeitos farmacológicos da Ayahuasca. O que não ocorre em Carvalho (2005). Desse modo, a sua proposta deinvestigação visou 
compreender os sentidos das transformações pessoais nos contextos rituais e interacionais da UDV.

Os resultados da pesquisa de Fernandes (2011) são: 1) a transformação consiste em um exame, responsabilidade e transformações caracterizadas em aspectos negativos para positivos, como admiração, valorização, respeito e relações de confiança; 2) esse processo envolve integrações de ordem social, psíquica e com o ambiente, principalmente na união com Deus; 3) são sempre relacionais e requerem tempo; 4) os ensinos e outros exemplos de transformações são fundamentais; 5) passam do conflito para a luz, paz e amor. Com o objetivo da descrição etnográfica, Fernandes (2011) apresentou uma documentação vasta a respeito das atividades do Núcleo Menino Deus, inclusive com inúmeras fotos das diversas atividades ocorridas nesse ambiente pesquisado.

$\mathrm{Na}$ interface dessa relação entre religião e saúde, Ricciardi (2008) enfatizou, em sua pesquisa de mestrado, "o uso da ayahuasca e a experiência de transformação alívio e cura na União do Vegetal (UDV)", uma investigação sobre o fenômeno da "cura religiosa" ou da "cura espiritual" (RICCIARDI, 2008, p. 11) através de um enfoque socioantropológico. O campo empírico foi o Núcleo Estrela da Manhã, localizado na região metropolitana de Salvador e cujos frequentadores são delineados em uma classe média, com nível de escolaridade entre o nível médio e superior. O objetivo era compreender os significados das aflições e as respectivas saídas de "um polo considerado negativo, que é a doença e a aflição, para um polo positivo, que é o alívio e a cura" (RICCIARDI, 2008, p. 9). Nesse bojo, a autora investigou tanto as experiências de patologias (como o 'câncer') quanto às experiências de toxicodependência.

Essas experiências, do "polo negativo", foram discutidas a partir do referencial proposto por Csordas (1997), da "fenomenologia cultural", na qual a ênfase é dada ao processo de "cura religiosa" e "terapêutica" do ponto de vista dos pacientes. Embora a autora ressalte que a UDV não se intitulecomo uma religião de cura e não tenha rituais específicos 
para esse propósito, com frequência ouvia alguns relatos de "curas espirituais". Um dos fenômenos que mais chamavam a atenção da autora é que desde o seu primeiro contato com a União do Vegetal ouvia relatos de pessoas que haviam chegado à instituição com problemas crônicos com as "drogas" e que haviam se transformado em pessoas mais calmas e tranquilas (CSORDAS, 1997). Com base nessas impressões lançou uma pergunta significativa: "mas por que uma religião que não se intitula de "cura", se tornou referência para a sociedade, em auxiliar dependentes químicos"? (RICCIARDI, 2008. p. 110).

Ricciardi (2008) qualificou a resolução para adição como "cura de dependência de drogas" e incluiu a toxicomania e o câncer no mesmo bojo das "curas religiosas". Nesse fragmento observa-se a designação de "cura espiritual" para pensar a dependência química do mesmo modo que foi pensada a "cura" do câncer de próstata. O fragmento de sua dissertação de mestrado explicita essa qualificação:

Temos um panorama de três pessoas: duas com problemas de dependência de drogas em um nível que comprometia suas relações sociais e profissionais, uma com problema físico que é o câncer de próstata [...]. O encontro com a religião UDV era um modo que eles buscaram para minimizar ou curar seus sofrimentos, buscando alivio ou cura para os respectivos problemas enfrentados (RICCIARDI, 2008, p. 121).

A autora traz contribuições significativas para a compreensão do processo de adesão religiosa de pessoas que experienciaram situações de 'sofrimento' e de 'dor' intrínsecos a toxicodependência. Segundo a autora, essa 'cura' dá-se devido a cinco fatores: ao querer dos indivíduos; ao chá; aos ensinos ou a doutrina religiosa; ao Mestre Gabriel; as pessoas. Contudo, Ricciardi faz uma ressalva importante, qual seja, os sócios da UDV não são em sua maior parte exdependentes químicos, diz a autora: "a maioria das pessoas que buscam conhecer a UDV não procuram a instituição diretamente para se curar. Pretendem ter um encontro consigo e com o sagrado" (RICCIARDI, 2008, p. 140). 
O uso da Hoasca, em contexto religioso, realizado por indivíduos com problemas com álcool e/ou drogas atravessa um número significativo dos trabalhos que apresentamos ao longo desse artigo. No entanto, em nossa concepção, o que justifica que haja uma lente de aumento voltada para essas relações, são os numerosos casos de, por assim dizer, sucesso, que a conjugação do sacramento Hoasca, com o ritual religioso e o ambiente de socialização da UDV, tem proporcionado às pessoas que estão em busca de resolução para essas questões relacionadas ao abuso de drogas.

Esse encontro 'duplo', que é mencionado por Ricciardi como aspecto característico das motivações de um quantitativo expressivo de pessoas para aproximação a UDV, constituiu-se como uma das abordagens propostas na dissertação de mestrado de Ribeiro (2009): "A busca de si numa religiosidade Hoasqueira". O recorte do objeto pretendeu-se a investigar as correlações entre as categorias da 'oralidade' - a fonte exclusiva de transmissão doutrinária - e a 'memória'. A pergunta que orientou a pesquisa foi: "o que pode a tradição do uso da transmissão oral e as configurações da categoria memória para a União do Vegetal nos informar acerca de sua cosmovisão"? (RIBEIRO, 2009, p. 24). O campo empírico para o desenvolvimento da sua pesquisa foram os Núcleos Rei Canãa e Príncipe Ram, ambos situados no Pará (PA). A base teóricometodológica ancorou-se na perspectiva interpretativista de Geertz (1979).

A resposta dada por Ribeiro (2009) entre as relações da 'memória' e da 'oralidade' são elucidativas para a compreensão das lógicas da aprendizagem doutrinária da 'cosmovisão' da UDV. A 'oralidade' na UDV trata-se de uma dimensão central. Segundo Ribeiro, nas palavras estão os aspectos basilares constitutivos da doutrina da instituição e são sistematizadas em três tipos: 1) as palavras a serem evitadas por terem um conteúdo depreciativo e/ou negativo; 2) a etimologia udivina; 3) as palavras específicas da gramática cultural da UDV. 
A "força da palavra" na União do Vegetal afigurou-se central na dissertação de mestrado de Souza (2010), de forma semelhante a Ribeiro (2009). Segundo o autor, "as palavras são utilizadas com cuidado e significação específica, pois direcionam e influenciam no efeito do vegetal, bem como na vida dos adeptos da União do Vegetal" (SOUZA, 2010, p. 115). O objetivo da pesquisa de Souza (2010) foi o de investigar a experiência de transformação de vida, o equilíbrio emocional e a saúde na visão dos sócios. A perspectiva teórica de LéviStrauss (1975) influenciou-o, sobretudo com os textos "o feiticeiro e a sua magia" e "a eficácia simbólica". A discussão teórica inscreveu-se na relação biopsicossocial (SOUZA, 2010). A observação participante deuse em São Luís (MA), no Núcleo Sereno do Mar, com aproximadamente sessenta e quatro sócios.

Segundo o autor, os sócios narravam uma situação de vida semelhante antes da adesão à UDV, que era caracterizável por um "estado de ruína física, psicológica e/ou econômica" e atribuem a força de vontade e ao uso do chá, considerado sagrado, uma restruturação psicofisiológica e social (SOUZA, 2010, p. 137). Entretanto, quando foram questionados a respeito da recepção de curas decorrentes de instâncias mágicas espirituais, não houve nenhuma narrativa a esse respeito. Houve, segundo ele, um processo de "cura indireta" atribuída à frequência ritual e à profissão religiosa, que são sistematizadas do seguinte modo: 1) ampliação da compreensão da vida; 2) alívio das aflições e ansiedades relativas às enfermidades, com aquisição de sentido espiritual para a vida e "conformação" (SOUZA, 2010, p. 137). Nas suas primeiras impressões no "campo", elencou inúmeras narrativas dos sócios da UDV acerca de uso de "drogas" lícitas e ilícitas antes da adesão religiosa, bem como a forma como se deu o abandono nesse processo. Esse fenômeno foi qualificado de "cura para dependência química" (SOUZA, 2010, p. 143).

A "conversão", "desconversão" e "reconversão" religiosa foram enfatizadas na dissertação de mestrado de Greganich (2010). A operação intelectual da comparação deu o tom dessa investigação, que 
enfatizou as trajetórias de sócios da União do Vegetal e membros do Santo Daime. A 'mobilidade' e a 'circulação' das pessoas por essas religiões foram pensadas através da metáfora do "peregrino" e do "convertido" de Hervieu-Léger (1999) e da "butinagem religiosa" de Edio Soares (2009). O campo empírico para consecução dessa pesquisa de "tradução cultural" e etnográfica é a Grande Porto Alegre e Porto Alegre (RS).

Greganich (2010) assentou a sua hipótese de trabalho no processo de 'conversão' na UDV e no Santo Daime, na interface da "estrutura" e da "experiência religiosa butinante" dados em um "Skill englobamento na força da burracheira" (GREGANICH, 2010, p.285). Como resultado, defende que as relações sociais são importantes como aspecto de aproximação e repulsão dos agentes, mas que não é um elemento conversivo relevante. Por outro lado, após a conversão as relações sociais auxiliariam na minimização de desconversões. Segundo a autora "todos os entrevistados possuíam uma narrativa na qual o motivo-chave da desconversão estava numa questão de relacionamento" (GREGANICH, 2010, p. 288). Embora discordassem de alguns dos sócios da UDV, os desconvertidos mantinham-se inabaláveis quanto as suas crenças nos "poderes da ayahuasca" e nos Mestres fundadores.

A "burracheira", léxico oriundo da gramática cultural udivina, afigurou-se como tema central na tese de doutorado de Melo (2010). Em suas palavras, "a interpretação que faço da noção de burracheira é a pedra angular da tese" (MELO, 2010, p. 10). O campo empírico dessa pesquisa foi o Núcleo Canário Verde (Brasília/DF). Segundo a autora, os membros desse Núcleo são da classe média do Distrito Federal. Embora diversa, a base teórica assentou-se com mais intensidade em Bastide (1975), com o propósito de reflexão dos significados das experiências de 'êxtase' sob o efeito da 'burracheira'.

Essa autora argumentou que não iria explorar a dimensão terapêutica, lúdica ou recreativa dos usos da ayahuasca, que a sua proposta seria a de pensar o mito e o rito "udevista" na semântica sacramental (MELO, 2010). Contudo, a temática da "cura" foi 
mobilizada pela autora na apresentação de uma "cura moral", como fruto da seguinte relação: o êxtase que é conduzido pela burracheira; a adesão religiosa; a transformação de um "eu" em outro "eu"; a graduação queé visível na forma da ascensão hierárquica. Nessa junção dar-se-ia o que ela chamou de "cura moral". Contudo, a autora não deixa claro o que ela chama desse novo "eu", bem como não faz referência aos atores sociais que deram base a essa afirmação através das narrativas nativas e/ou dos fragmentos das entrevistas, tampouco apresenta as descrições etnográficas do seu diário de campo nessa direção de exemplificação. Embora tenha realizado o trabalho de campo no Núcleo Canário Verde, não há uma descrição que apresente as pessoas que balizaram a sua pesquisa.

Nesse trabalho, há uma vasta apresentação do repertório das palavras do Mestre Gabriel, o que na ontologia da União do Vegetal tem um valor fundante e crucial. Todavia, de dificil acesso para além do contexto ritual para aqueles que ainda não fazem parte da direção do Centro (Corpo do Conselho e Quadro de Mestres). A nosso ver, reside nesse trabalho, portanto, um investimento mais caro à teologia do que à antropologia, que historicamente prima pela relacionalidade, intersubjetividade e interconhecimento etnográfico entre os pesquisados-pesquisados/ pesquisador-pesquisados, nas análises tanto clássicas quanto contemporâneas. Essa afirmação se dá, doravante a ênfase que é dada a descrição da doutrina da União do Vegetal, deixando-se de lado as interações, expectativas, reações e narrativas dos pesquisados diante das suas mais diversas experiências. Por sua vez, quando Melo (2010) descreve as trajetórias dos sócios da UDV, faz de forma indireta, ou seja, coletando as informações e os dados com pessoas que não pertencem mais à instituição. Desse modo e por essa via, essa autora escreveu a respeito das histórias de vida de alguns dos sócios do Quadro de Mestre, da "segunda geração", aqueles que foram formados e recebidos na UDV pelos Mestres que conheceram o Mestre Gabriel e das mãos deles receberam o título de Mestres. 
Esse percurso de revisão da literatura em dissertações de mestrado e teses de doutorado que abordaram o Centro Espírita Beneficente União do Vegetal como tema de pesquisa torna visível que, embora haja evidências da recorrente filiação religiosa de 'drogadictos' (HENMAM, 1986; BRISSAC, 1999; LABIGALINI, 1998; BARBOSA, 2001; SOUZA, 2010; MELO, 2010; GREGANICH, 2010), não havia nenhuma pesquisa antropológica que houvesse focalizado as lentes para pensar nas experiências e percepções dos sócios da UDV que vivenciaram problemas com o uso de "drogas" antes e/ou durante o processo de adesão a esse Centro Espírita. A dependência química era tratada de forma escamoteada, sobretudo como variável secundária. A partir dessa verificação na bibliografia descrita, Luz (2015) teve o objetivo de investigar o fenômeno da 'adesão' religiosa à União do Vegetal em sua dissertação de mestrado (2015), que foi defendida no Programa de PósGraduação em Sociologia e Antropologia (PPGSA/IFCS/UFRJ). Nesse texto, intitulado de "Jardim do Norte", o autor teve o objetivo de detalharas características desse processo específico de adesão religiosa hoasqueira ao CEBUDV, no Núcleo Reis Magos, com um histórico pregresso ou em curso de drogadicção. Dentre as suas principais contribuições está o argumento de que não se trata de "cura moral", "cura religiosa", nem tampouco de "cura espiritual", pois não se verificou, por parte dos pesquisados por ele, alguma narrativa na direção desse agenciamento religioso enquanto uma instância terapêutica.

O objetivo da dissertação de mestrado de Luz (2015) foi o de responder à seguinte pergunta: "por que essas pessoas buscam a uma instância religiosa onde se bebe o psicoativo Hoasca em momentos de reveses que envolvem a drogadicção"? (LUZ 2015, p. 136). A hipótese de trabalho defendida por Luz (2015), para responder a essa pergunta, é a de que nesse contexto 'nativo' não há "cura religiosa" para dependência química, pois na percepção dos 'pesquisados' não há um processo de adoecimento como motivação para a agência religiosa. Há sim, segundo esse pesquisador, uma assunção da itineração em busca de 
experiências místicas de contato com o "sagrado" que, a posteriori, poderão desenvolver um processo de "cuidado em sentido religioso" pela via da adesão e do processo de crescimento das pessoas através das narrativas e das práticas assentadas na moralidade cotidiana, que são apreendidas e vivenciadas nesse setting.

Nesse sentido, os Mestres da União do Vegetal desempenham, segundo Luz (Ibidem), um papel fundamental na dinâmica pedagógica espiritual, na medida em que são os responsáveis hierárquicos pela transmissão dos ensinos, bem como pelo acompanhamento do desenvolvimento espiritual dos discípulos que buscam uma transformação de si conforme a moral udivina que é vislumbrada na vida comunitária, nas sessões espíritas e nas demais atividades realizadas pela e na UDV. Esse convite é apresentado nas sessões espíritas através das doutrinações, que expressam a necessidade da transformação espiritual nos léxicos: "clarear a consciência", "martelar a memória", "graduação espiritual".

Como demonstra Luz (2015), não há nenhum tratamento especial para essas pessoas, mas há um novo "irmão" e/ou "irmã" em potencial, que está imerso em um processo lento e gradual de filiação à UDV e em desenvolvimento espiritual. Em alguns casos pode haver um desdobramento salutar para casos de dependência química que, em grande parte,passam por recaídas, abandonos, retornos e continuidades. Através da percepção dos Mestres de que há o abandono dos usos de "drogas" lícitas e ilícitas por parte dessas pessoas, e o fortalecimento em tornar-se um 'irmão' e/ou "irmã”, com base na adoção da prática cotidiana dos princípios doutrinários previstos nas leis do Centro Espírita, há uma convocação para ascensão dentro da hierarquia que possibilitará o conhecimento de alguns segredos. Essa ascensão hierárquica pode ser compreendida como uma resposta institucional positiva e de reforço ante a abstinência. Ao mesmo tempo, convoca-se para que se continue na aquisição das habilidades que são ensinadas pela União do Vegetal e que são vitais para a manutenção de uma vida saudável frente à dependência química: 1) aprender a 
aprender; 2) uma percepção espiritual da vida que proporcione uma compreensão mais adequada de "si", dos seus limites e dificuldades na lógica nativa do "conhece-te a ti mesmo" através do "examinar-se a si mesmo"; 3) usos adequados das palavras; 4) educação da atenção com o propósito de "graduação da memória"; 5) mudanças de comportamento devido às experiências à luz da Hoasca; 6) engajamento com a "obra do Mestre"; 7) vínculos de irmandade, gratidão e fidelidade com o desenvolvimento de relações de confiança que passam pela reciprocidade de convites para apadrinhamento de filhos, casais e visitas domésticas. Esses são alguns dos resultados apresentados na dissertação de mestrado de Luz (2015).

$\mathrm{Na}$ interface dessa discussão, insere-se a dissertação de mestrado de Aguiar (2016), defendida no Programa de Pós-Graduação em Politicas Públicas e Sociedade, na Universidade Estadual do Ceará. Essa pesquisa trouxe uma contribuição importante: o recorte analítico geracional. A partir dessa inserção e com o foco investigativo na juventude, enquanto sujeitos dessa pesquisa, propôs-se desenvolver uma triangulação, cujo objetivo é ode esmiuçar as relações entre o uso de substâncias psicoativas, religião e juventude. Esse tema de pesquisa surgiu, para Aguiar, por meio das suas observações no cotidiano das demandas politicas e dos debates no cenário legislativo do Estado do Ceará, dada a sua atuação como consultora técnica da Assembleia Legislativa do referido Estado. Por outro lado, somam-se às questões de correntes da sua prática profissional, aquelas que surgiram devido a sua vivência enquanto sócia do CEBUDV há muitos anos.

Assim, por meio dessa dupla inserção, profissional e religiosa, Aguiar (2016) formulou a proposta de pesquisar e compreender, por meio de um estudo de caso, que iniciou-se no Núcleo Fortaleza (CE) e depois estendeu-se para outros Núcleos da região metropolitana da capital do Estado do Ceará, como que “jovens-adultos" da UDV, que bebem com regularidade a Hoasca e são participantes das práticas religiosas e comunitárias no âmbito desse Centro, relacionam-se com as drogas e as questões que são variantes de seus diversos usos no 
contexto atual. Essa pesquisa desenvolveu-se através de uma série de técnicas para levantamento de dados. Entre essas técnicas estão: uma etnografia dos pares, por meio da qual dois "jovens-adultos" foram os pesquisadores, aplicação de questionários estruturados e semiestruturados, dois grupos focais e entrevistas individuais.

Entre os principais resultados dessa dissertação de mestrado podemos apontar para o fato de que essa proposta religiosa tem atuado por meio de diversas atividades, descritas e exemplificadas por Aguiar (2016), para esse público pesquisado (sessões, orientação espiritual, palestras, arte, lazer, cultura, laços de amizade, mutirões e trabalhos voluntários), como um importante fator de diminuição do impacto e dos riscos do uso de substâncias psicoativas lícitas (cigarro e bebidas alcoólicas) e ilícitas (maconha, cocaína, crack, LSD, Ecstasy). Nessa direção analítica, será exemplificado que apenas três, dentre os quarenta e um sujeitos da pesquisa, disseram estar fazendo uso de algum tipo de substâncias psicoativas como o álcool e/ou a maconha no momento atual (AGUIAR, 2016, p. 104). Outro resultado dissertado nessa linha argumentativa é o de que os ensinos espirituais do Centro agem como uma "instância de produção de sentidos e significações para os jovens-adultos" em três aspectos: espiritual, existencial e para a vida, através do qual eles passam a examinar os seus pensamentos, sentimentos e ações (AGUIAR, 2016, p. 139).

Para fecharmos esse percurso de revisão bibliográfica, incluímos a dissertação de mestrado de Lídice Canela, intitulada: "O Lótus e a Rosa: aspectos éticos entre o Budismo e a União do Vegetal". O trabalho foi defendido no ano de 2016 no Programa de Pós-Graduação em Ciências das Religiões da Universidade Federal da Paraíba (UFPB) e teve o objetivo de fazer uma comparação entre duas tradições religiosas distintas, o Budismo e a UDV. Essa comparação se deu através de alguns aspectos, são eles: a análise dos códigos de conduta, a formulação dos traços éticos e das virtudes. Esses são alguns dos traços mais fortes dessas duas tradições religiosas. A autora aponta, ainda, como característica comum, a oralidade, como caminho para 
trazer a doutrina e os ensinamentos, o que nos remete a um forte predominio da oralidade em detrimento da escrita. Ou seja, são duas tradições que privilegiam o uso e o compromisso com a palavra na prática cotidiana de seus membros.

Como referência teórica a autora se utiliza do conceito de ética, tal como trazido por Aristóteles, ou seja, a ética como "modo de ser" ou "caráter", procurando analisar como a introjeção dos ensinos e da doutrina do CEBUDV e do Budismo conduzem a ações transformadoras das condutas individuais. Neste sentido, a constituição ética é pautada nos exemplos dados pelos seus guias espirituais, respectivamente Buda e Mestre Gabriel, aos seus primeiros discipulos como modelos de condutas pelos quais os discípulos devem procurar seguir. Ou seja, ambas as religiões exercem um alto grau de inscrição nas vidas cotidianas daqueles que aderem a essas propostas ensejadas e descritas. A autora analisa, ainda,os símbolos que são utilizados por estas tradições como forma de enriquecimento da consciência individual e coletiva do grupo. Assim, examina a "Flor de lótus" como símbolo de pureza para a tradição budista, já que esta planta atravessa as águas barrentas sem se manchar, constituindo-se como símbolo no caminho da iluminação. Da mesma forma, examina a "rosa" como símbolo de orientação na busca por um caminho de perfeição e pureza. A "Flor de Lótus" como metáfora e comparação à "Rosa".

Um dos aspectos mais originais desse trabalho é a maneira como Canela (2016) procura traçar um paralelo entre as duas tradições religiosas pesquisadas, no que toca ao aprendizado que é voltado para a destruição das ilusões e o desenvolvimento da sabedoria. Nas duas tradições o indivíduo é tido como responsável pela sua própria libertação. Esse caminho da libertação passa necessariamente por um aperfeiçoamento da moralidade, que é entendido pela correção e que é expresso naquilo que se fala, bem como na ação e no viver de modo mais geral e abrangente. Portanto, o caminho ético dessas tradições relaciona-se com um treinamento que se inicia pela prática cotidiana que se dá no processo de transformação, de dentro para fora. Em 
sintese, essa dissertação de mestrado de Lídice Canela visa demonstrar que, tanto no Budismo quanto na UDV, os ensinos são voltados às práticas virtuosas que tem o objetivo de orientar os seus praticantes a desenvolverem uma conduta que seja moralmente correta, à luz dos seus sistemas ontológicos, bem como para que a prática prevaleça sobre a teorização doutrinária.

\section{Conclusão}

Nesse texto, não abordamos as pesquisas produzidas a respeito dos aspectos farmacológicos do chá Hoasca e que resultaram em um considerável número de artigos que foram publicados em periódicos nacionais e internacionais. Algumas destas pesquisas foram realizadas com apoio logístico do CEBUDV, tendo seus sócios como voluntários, a exemplo do "Projeto Hoasca" e do "Projeto Hoasca com jovens" (BERNARDINO-COSTA, 2011), ambos conduzidos por uma cooperação multinacional de universidades e que resultaram na base do que se conhece, na atualidade, em termos da farmacologia humana do chá Hoasca, os seus efeitos e a sua inofensividade ao organismo humano.

Esse artigo teve como foco de análise e leitura, os trabalhos realizados em nível de mestrado e doutorado, no espaço temporal compreendido entre os anos de 1995 e 2016, no que toca à produção do conhecimento acadêmico relativo ao CEBUDV. Como podemos perceber, o campo ayahuasqueiro é muito recente em termos da pesquisa e produção acadêmica. Pois, como observamos, os trabalhos acerca das religiões que compõem esse campo surgiram no início dos anos 1980 e, mais especificamente, em relação ao CEBUDV as pesquisas se iniciaram nos anos 1990. O que propomos fazer, nesse texto, tratou-se de uma breve, mas importante revisão dos trabalhos acadêmicos a respeito desta religião, cujo objetivo foi o de traçar a localização, para os futuros pesquisadores, a respeito daquilo que já foi tematizado, escrito e debatido, bem como demonstrar que ainda há muito a ser feito e revisitado. A tabela abaixo faz uma breve descrição dos trabalhos analisados neste artigo: 
Quadro 1: Síntese das teses e dissertações de mestrado a respeito do CEBUDV.

\begin{tabular}{|c|c|c|c|c|}
\hline Título, Autor e ano & $\begin{array}{l}\text { Dissertação ou } \\
\text { Tese/Programa }\end{array}$ & Objetivos & Desenho do estudo & Publicação \\
\hline $\begin{array}{l}\text { Título: O fenômeno do chá e } \\
\text { a religiosidade cabocla: um } \\
\text { estudo centrado na União do } \\
\text { Vegetal. Autor: Afrânio } \\
\text { Patrocínio de Andrade. } \\
\text { Ano: } 1995\end{array}$ & $\begin{array}{l}\text { Dissertação } \\
\text { Programa de } \\
\text { Pós-Graduação } \\
\text { em Ciências da } \\
\text { Religião do } \\
\text { Instituto } \\
\text { Metodista de } \\
\text { Ensino Superior } \\
\text { - São Bernardo } \\
\text { do Campo - SP. }\end{array}$ & $\begin{array}{l}\text { Investigar o por que } \\
\text { da adesão das pessoas } \\
\text { a UDV em contexto } \\
\text { urbano; } \\
\text { Verificar se o sistema } \\
\text { de crenças da religião } \\
\text { se encaixa nos } \\
\text { anseios do que o } \\
\text { autor nomeou de } \\
\text { "classe média culta". }\end{array}$ & $\begin{array}{l}\text { Pesquisa de campo no } \\
\text { Núcleo São João Batista, } \\
\text { localizado em São Paulo- } \\
\text { SP; } \\
\begin{array}{l}\text { Aplicação } \\
\text { questionários } \\
\text { levantamento de dados } \\
\text { estatísticos. }\end{array}\end{array}$ & $\begin{array}{l}\text { Artigos em periódicos } \\
\text { nacionais e em livros. }\end{array}$ \\
\hline $\begin{array}{l}\text { Título: O uso de ayahuasca } \\
\text { em um contexto religioso por } \\
\text { ex-dependentes de álcool - um } \\
\text { estudo qualitativo. } \\
\text { Autor: Eliseu Labigalini Jr. } \\
\text { Ano: } 1998\end{array}$ & $\begin{array}{l}\text { Dissertação - } \\
\text { Programa de } \\
\text { Pós-Graduação } \\
\text { em Saúde } \\
\text { Mental da } \\
\text { Universidade } \\
\text { Federal de São } \\
\text { Paulo } \\
\text { (UNIFESP). }\end{array}$ & 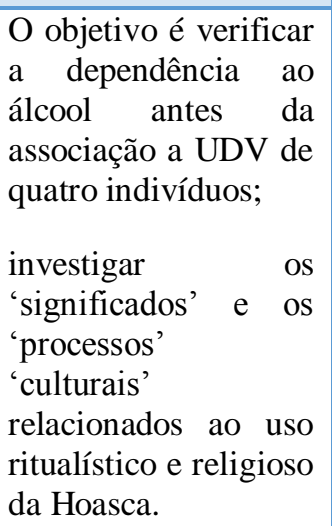 & $\begin{array}{l}\text { Metodologia qualitativa, } \\
\text { descrição etnográfica e } \\
\text { observação participante. }\end{array}$ & $\begin{array}{l}\text { Artigos em periódicos } \\
\text { nacionais. }\end{array}$ \\
\hline $\begin{array}{l}\text { Título: A Estrela do Norte } \\
\text { Iluminando até o Sul: uma } \\
\text { Etnografia da União do } \\
\text { Vegetal em um Contexto } \\
\text { Urbano. } \\
\text { Autor: Sérgio G. T. Brissac } \\
\text { Ano: } 1999\end{array}$ & $\begin{array}{l}\text { Dissertação - } \\
\text { Programa de } \\
\text { Pós-Graduação } \\
\text { em } \\
\text { Antropologia } \\
\text { Social da } \\
\text { Universidade } \\
\text { Federal do Rio } \\
\text { de Janeiro } \\
\text { (UFRJ). }\end{array}$ & $\begin{array}{l}\text { Explicar } \\
\text { funcionamento da } \\
\text { UDV por meio de } \\
\text { três eixos: o modelo } \\
\text { organizacional, a } \\
\text { narrativa histórica e a } \\
\text { experiência } \\
\text { simbólica; } \\
\text { Discorrer a respeito } \\
\text { da doutrina udivina a } \\
\text { partir de publicações } \\
\text { oficiais da religião. }\end{array}$ & 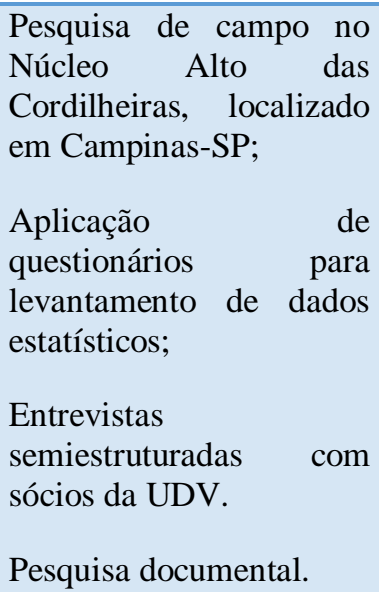 & $\begin{array}{l}\text { Artigos em periódicos } \\
\text { nacionais e em livros. }\end{array}$ \\
\hline $\begin{array}{l}\text { Título: Psiquiatria cultural do } \\
\text { uso ritualizado de um } \\
\text { alucinógeno no contexto } \\
\text { urbano: uma investigação dos } \\
\text { estados de consciência } \\
\text { induzidos pela ingestão da } \\
\text { ayahuasca no santo daime e } \\
\text { união do vegetal em } \\
\text { moradores de São Paulo } \\
\text { Autor: Paulo César Ribeiro } \\
\text { Barbosa }\end{array}$ & $\begin{array}{l}\text { Dissertação - } \\
\text { Programa de } \\
\text { Pós-Graduação } \\
\text { em Ciências } \\
\text { Médicas da } \\
\text { Universidade } \\
\text { Estadual de } \\
\text { Campinas } \\
\text { (UNICAMP). }\end{array}$ & $\begin{array}{l}\text { Avaliar os efeitos } \\
\text { psicológicos, a curto } \\
\text { prazo, da ingestão de } \\
\text { Hoasca/Ayahuasca } \\
\text { em indivíduos que a } \\
\text { utilizaram-na em } \\
\text { contextos ritualísticos } \\
\text { e religiosos, no Santo } \\
\text { Daime e na UDV } \\
\text { pela primeira vez; } \\
\text { Verificar a redução } \\
\text { de sintomas } \\
\text { psiquiátricos menores }\end{array}$ & $\begin{array}{l}\text { Avaliação de } 28 \text { sujeitos, } \\
19 \text { que beberam o chá na } \\
\text { doutrina do Santo Daime } \\
\text { e nove que beberam o } \\
\text { chá no ritual da UDV; } \\
\text { Os sujeitos foram } \\
\text { avaliados quatro dias } \\
\text { antes da primeira } \\
\text { experiência com o chá e } \\
\text { duas semanas após essa } \\
\text { experiência; } \\
\text { Foram conduzidas }\end{array}$ & $\begin{array}{l}\text { Artigos em periódicos } \\
\text { nacionais e internacionais. }\end{array}$ \\
\hline
\end{tabular}




\begin{tabular}{|c|c|c|c|c|}
\hline Ano: 2001 & & $\begin{array}{l}\text { entre aqueles que } \\
\text { beberam o chá no } \\
\text { ritual do Santo Daime } \\
\text { e da UDV. }\end{array}$ & $\begin{array}{l}\text { Entrevistas } \\
\text { semiestruturadas e uma } \\
\text { escala de medida } \\
\text { psiquiátrica foram } \\
\text { utilizadas para mensurar } \\
\text { as expectativas em } \\
\text { relação a experiência } \\
\text { com o chá, assim como } \\
\text { obter o status de saúde } \\
\text { mental; } \\
\text { entrevista } \\
\text { semiestruturada sobre a } \\
\text { fenomenologia } \\
\text { estados alterados de } \\
\text { consciência. }\end{array}$ & \\
\hline $\begin{array}{l}\text { Título: Em } \begin{array}{lr}\text { Busca do } \\
\text { Encontro: a } \\
\text { numinosa no } \\
\text { religioso da União do Vegetal. }\end{array} \\
\text { Autor: Tatiana Carvalho } \\
\text { Ano: } 2005\end{array}$ & $\begin{array}{l}\text { Dissertação - } \\
\text { Programa de } \\
\text { Pós-Graduação } \\
\text { em Psicologia } \\
\text { Clínica da } \\
\text { Pontifícia } \\
\text { Universidade } \\
\text { Católica do Rio } \\
\text { de Janeiro } \\
\text { (PPPC-PUC). }\end{array}$ & $\begin{array}{l}\text { Verificar a partir das } \\
\text { narrativas dos sócios } \\
\text { do CEBUDV, o } \\
\text { sentimento do } \\
\text { sagrado ou mais } \\
\text { especificamente, da } \\
\text { demanda numinosa. } \\
\text { Verificar a visão de } \\
\text { mundo daqueles que } \\
\text { bebem a Hoasca a } \\
\text { partir do encontro } \\
\text { com a espiritualidade } \\
\text { proporcionado pela } \\
\text { ingestão ritualística } \\
\text { do chá. }\end{array}$ & $\begin{array}{l}\text { Pesquisa de campo, } \\
\text { entrevistas } \\
\text { semiestruturadas, } \\
\text { histórias de vida, } \\
\text { observação participante e } \\
\text { descrição etnográfica. } \\
\text { O "campo" de pesquisa } \\
\text { desenvolveu-se no } \\
\text { Núcleo Pupuramanta, } \\
\text { situado no Rio de } \\
\text { Janeiro-RJ. }\end{array}$ & $\begin{array}{l}\text { Artigos em periódicos } \\
\text { nacionais. }\end{array}$ \\
\hline $\begin{array}{l}\text { Título: O Uso da Ayahuasca e } \\
\text { a Experiência de } \\
\text { Transformação, Alívio e Cura, } \\
\text { na União do Vegetal (UDV). } \\
\text { Autor: Gabriela Santos } \\
\text { Ricciardi } \\
\text { Ano: } 2008\end{array}$ & $\begin{array}{l}\text { Dissertação - } \\
\text { Programa de } \\
\text { Pós-Graduação } \\
\text { em Ciências } \\
\text { Sociais da } \\
\text { Universidade da } \\
\text { Federal } \\
\text { Bahia (UFBA). }\end{array}$ & $\begin{array}{l}\text { Compreender a partir } \\
\text { da narrativa de sócios } \\
\text { da UDV os } \\
\text { significados } \\
\text { relacionados } \\
\text { transformação e a } \\
\text { "cura" por meio do } \\
\text { uso ritualístico } \\
\text { religioso da Hoasca; } \\
\text { Investigar as as } \\
\text { experiências de } \\
\text { patologias (como o } \\
\text { 'câncer'), assim } \\
\text { como às experiências } \\
\text { detoxicodependência. }\end{array}$ & $\begin{array}{l}\text { Pesquisa de campo, } \\
\text { entrevistas } \\
\text { semiestruturadas, } \\
\text { histórias de vida, } \\
\text { observação participante e } \\
\text { descrição etnográfica. } \\
\text { O "campo" de pesquisa } \\
\text { desenvolveu-se no } \\
\text { Núcleo Estrela da Manhã, } \\
\text { situado na cidade de } \\
\text { Salvador-BA. }\end{array}$ & $\begin{array}{l}\text { Artigos em periódicos } \\
\text { nacionais e em livros. }\end{array}$ \\
\hline $\begin{array}{l}\text { Título: Follow-up em saúde } \\
\text { mental de pessoas que } \\
\text { experimentam pela primeira } \\
\text { vez a ayahuasca em contexto } \\
\text { religioso. } \\
\text { Autor: Paulo César Ribeiro } \\
\text { Barbosa } \\
\text { Ano: } 2008\end{array}$ & $\begin{array}{l}\text { Doutorado - } \\
\text { Programa de } \\
\text { Pós-Graduação } \\
\text { em Ciências } \\
\text { Médicas da } \\
\text { Universidade } \\
\text { Estadual de } \\
\text { Campinas } \\
\text { (UNICAMP). }\end{array}$ & $\begin{array}{l}\text { O objetivo foi avaliar } \\
\text { os efeitos de sintoma } \\
\text { psiquiátrico, de } \\
\text { personalidade } \\
\text { qualidade de vida } \\
\text { antes da primeira } \\
\text { experiência e após } \\
\text { seis meses da } \\
\text { ingestão de } \\
\text { Hoasca/Ayahuasca }\end{array}$ & $\begin{array}{l}\text { Foram avaliados } 23 \\
\text { sujeitos, } 15 \text { que beberam } \\
\text { o chá na doutrina do } \\
\text { Santo Daime e } 8 \text { que } \\
\text { beberam o chá no ritual } \\
\text { da UDV. Eles foram } \\
\text { avaliados por meio de } \\
\text { entrevistas } \\
\text { semiestruturadas e escala } \\
\text { de medida psiquiátrica }\end{array}$ & $\begin{array}{l}\text { Artigos em periódicos } \\
\text { nacionais e internacionais. }\end{array}$ \\
\hline
\end{tabular}




\begin{tabular}{|c|c|c|c|c|}
\hline & & $\begin{array}{l}\text { em indivíduos que a } \\
\text { utilizaram em } \\
\text { contextos ritualisticos } \\
\text { religiosos no Santo } \\
\text { Daime e na UDV } \\
\text { pela primeira vez. }\end{array}$ & $\begin{array}{l}\text { quatro dias antes da } \\
\text { primeira experiência com } \\
\text { o chá, duas semanas após } \\
\text { essa experiência e após } \\
\text { seis meses com a } \\
\text { finalidade de obter o } \\
\text { status de saúde mental; }\end{array}$ & \\
\hline $\begin{array}{l}\text { Título: A busca de si numa } \\
\text { religião hoasqueira: oralidade, } \\
\text { memória e conhecimento na } \\
\text { União do Vegetal. } \\
\text { Autor: Dilma Ribeiro } \\
\text { Ano: } 2009\end{array}$ & $\begin{array}{l}\text { Dissertação - } \\
\text { Programa de } \\
\text { Pós-Graduação } \\
\text { em Ciências } \\
\text { Sociais da } \\
\text { Universidade } \\
\text { Federal do Pará } \\
\text { (UFPA). }\end{array}$ & 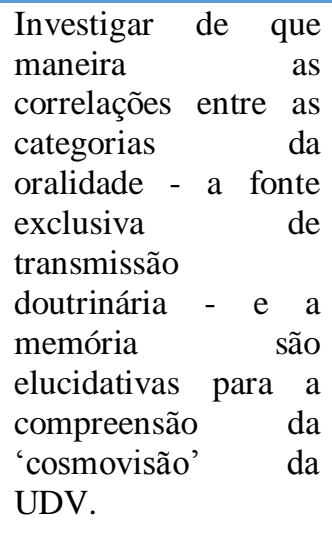 & $\begin{array}{l}\text { Metodologia qualitativa, } \\
\text { descrição etnográfica e } \\
\text { observação participante; } \\
\text { O “campo" de pesquisa } \\
\text { desenvolveu-se nos } \\
\text { Núcleos Rei Canaã e } \\
\text { PrincípeRam, situados na } \\
\text { cidade de Belém-PA. }\end{array}$ & \\
\hline $\begin{array}{l}\text { Título: Ayahuasca, } \\
\text { Identificando Sentidos:o uso } \\
\text { ritual da bebida na União do } \\
\text { Vegetal. } \\
\text { Autor: Valdir Mariano Souza } \\
\text { Ano: } 2010\end{array}$ & $\begin{array}{l}\text { Dissertação - } \\
\text { Programa de } \\
\text { Pós-Graduação } \\
\text { em Ciências } \\
\text { Sociais da } \\
\text { Universidade } \\
\text { Federal do } \\
\text { Maranhão } \\
\text { (UFMA). }\end{array}$ & $\begin{array}{lr}\text { O objetivo da } \\
\text { pesquisa } & \text { foi } \\
\text { investigar } & \text { a } \\
\text { experiência } & \text { de } \\
\text { transformação na } & \text { vida, o equilíbrio } \\
\text { emocional e da saúde } \\
\text { na visão dos sócios a } \\
\text { partir da "força da } \\
\text { palavra". }\end{array}$ & $\begin{array}{l}\text { Metodologia qualitativa, } \\
\text { descrição etnográfica e } \\
\text { observação participante; } \\
\text { O “campo" de pesquisa } \\
\text { desenvolveu-ser no } \\
\text { Núcleo Sereno do Mar, } \\
\text { localizado em São Luiz- } \\
\text { MA. }\end{array}$ & \\
\hline $\begin{array}{l}\text { Título: "Entre a Rosa e o } \\
\text { Beija-flor": } \\
\text { Antropológico de Trajetórias } \\
\text { na União do Vegetal e no } \\
\text { Santo Daime. } \\
\text { Autor: Jéssica Greganich. } \\
\text { Ano: } 2010\end{array}$ & $\begin{array}{l}\text { Dissertação - } \\
\text { Programa de } \\
\text { Pós-Graduação } \\
\text { em } \\
\text { Antropologia } \\
\text { Social Da } \\
\text { Universidade } \\
\text { Federal do Rio } \\
\text { Grande do Sul } \\
\text { (UFRGS). }\end{array}$ & $\begin{array}{l}\text { O objetivo é verificar } \\
\text { o que a autora } \\
\text { nomeou } \\
\text { "conversão", } \\
\text { "desconversão" } \\
\text { "reconversão" } \\
\text { Santo Daime e no } \\
\text { UDV a partir das } \\
\text { relações sociais } \\
\text { constituída nestas } \\
\text { religiões. }\end{array}$ & $\begin{array}{l}\text { Pesquisa de campo, } \\
\text { entrevistas } \\
\text { semiestruturadas, } \\
\text { histórias de vida, } \\
\text { observação participante e } \\
\text { metodologia } \\
\text { comparativa. } \\
\text { O "campo" de pesquisa } \\
\text { desenvolveu-se na grande } \\
\text { Porto Alegre. }\end{array}$ & \\
\hline $\begin{array}{l}\text { Título: "Beber na } \\
\text { Fonte":adesão e transformação } \\
\text { na União do Vegetal. } \\
\text { Autor: Rosa Virgínia Melo } \\
\text { Ano: } 2010\end{array}$ & $\begin{array}{l}\text { Doutorado - } \\
\text { Programa de } \\
\text { Pós-Graduação } \\
\text { em } \\
\text { Antropologia } \\
\text { Social Da } \\
\text { Universidade de } \\
\text { Brasília (UnB). }\end{array}$ & $\begin{array}{l}\text { O objetivo da tese é } \\
\text { analisar o êxtase que } \\
\text { é conduzido pela } \\
\text { burracheira; a adesão } \\
\text { religiosa; a } \\
\text { transformação de um } \\
\text { "eu" em um outro } \\
\text { "eu"; a graduação } \\
\text { que é visível na } \\
\text { forma da ascensão } \\
\text { hierárquica. }\end{array}$ & $\begin{array}{l}\text { Trabalho de campo } \\
\text { desenvolvido no Nucleo } \\
\text { Canário } \\
\text { localizado na cidade de } \\
\text { Brasília-DF. }\end{array}$ & $\begin{array}{l}\text { Artigos em periódicos } \\
\text { nacionais e internacionais. } \\
\text { Artigo publicado em livro. }\end{array}$ \\
\hline $\begin{array}{l}\text { Título: } \quad \text { Transformações } \\
\text { pessoais na União do Vegetal }\end{array}$ & $\begin{array}{l}\text { Doutorado - } \\
\text { Programa de } \\
\text { Pós-Graduação }\end{array}$ & $\begin{array}{lr}\text { O autor } & \text { buscou } \\
\text { compreender } & \text { os } \\
\text { sentidos } & \text { das } \\
\end{array}$ & $\begin{array}{l}\text { Metodologia qualitativa, } \\
\text { descrição etnográfica e }\end{array}$ & \\
\hline
\end{tabular}




\begin{tabular}{|c|c|c|c|c|}
\hline $\begin{array}{l}\text { Autor: Cícero Guella } \\
\text { Fernandes } \\
\text { Ano: } 2011\end{array}$ & $\begin{array}{lr}\text { em } r & \text { Filosofia, } \\
\text { Ciências } & \mathrm{e} \\
\text { Letras } & \text { de } \\
\text { Ribeirão } & \text { Preto } \\
\text { (SP), } & \\
\text { Universidade de } \\
\text { São } & \text { Paulo } \\
\text { (USP). }\end{array}$ & $\begin{array}{l}\text { transformações } \\
\text { pessoais nos } \\
\text { contextos rituais } \mathrm{e} \\
\text { interacionais } \mathrm{da} \\
\text { UDV. }\end{array}$ & $\begin{array}{l}\text { observação participante; } \\
\text { O “campo" de pesquisa } \\
\text { desenvolveu-se r no } \\
\text { Núcleo Menino Deus, } \\
\text { localizado em Manaus- } \\
\text { AM. }\end{array}$ & \\
\hline $\begin{array}{l}\text { Título: Jardim do Norte: } \\
\text { experiências de sofrimento e } \\
\text { desenvolvimento espiritual de } \\
\text { adictos na União do Vegetal. } \\
\text { Autor: Emanuel Luz Silva } \\
\text { Ano: } 2015\end{array}$ & $\begin{array}{l}\text { Dissertação - } \\
\text { Programa de } \\
\text { Pós-Graduação } \\
\text { em } \\
\text { Antropologia } \\
\text { da Universidade } \\
\text { Federal do Rio } \\
\text { de Janeiro } \\
\text { (UFRJ). }\end{array}$ & $\begin{array}{l}\text { O objetivo da } \\
\text { dissertação é verificar } \\
\text { porque pessoas } \\
\text { buscam a uma } \\
\text { instância religiosa } \\
\text { onde se bebe o } \\
\text { psicoativo Hoasca em } \\
\text { momentos de reveses } \\
\text { que envolvem a } \\
\text { drogadicção; } \\
\text { Em que medida o } \\
\text { setting contribui para } \\
\text { o desenvolvimento de } \\
\text { um "cuidado de si" } \\
\text { no tocante a adicção } \\
\text { de substâncias lícitas } \\
\text { e ilícitas em um } \\
\text { contexto religioso. }\end{array}$ & 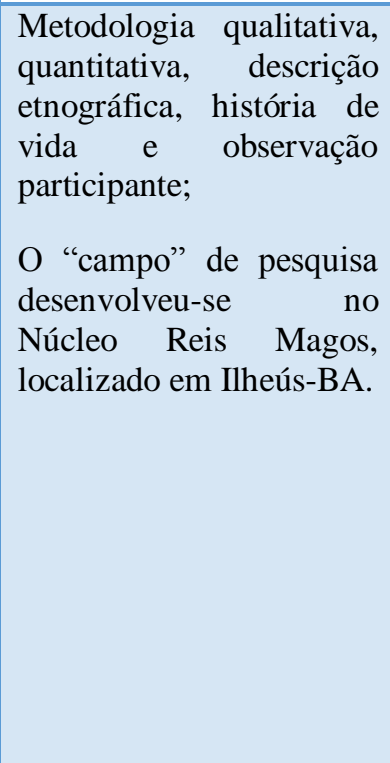 & \\
\hline $\begin{array}{l}\text { Título: Jovens da União do } \\
\text { Vegetal no Ceará: Práticas } \\
\text { ritualísticas e vida comunitária } \\
\text { no convívio com as drogas. } \\
\text { Autor:Rosileuda Pontes } \\
\text { Aguiar } \\
\text { Ano: } 2016\end{array}$ & $\begin{array}{l}\text { Dissertação }- \\
\text { Programa de } \\
\text { Pós-Graduação } \\
\text { em Políticas } \\
\text { Públicas e } \\
\text { Sociedade da } \\
\text { Universidade } \\
\text { Estadual do } \\
\text { Ceará (UECE). }\end{array}$ & $\begin{array}{l}\text { O objetivo da } \\
\text { pesquisa foi verificar } \\
\text { como que "jovens- } \\
\text { adultos", que são da } \\
\text { UDV e bebem com } \\
\text { regularidade a } \\
\text { Hoasca, bem como } \\
\text { são participantes das } \\
\text { práticas religiosas e } \\
\text { comunitárias no } \\
\text { âmbito desse Centro, } \\
\text { relacionam-se com as } \\
\text { drogas e as questões } \\
\text { que são variantes de } \\
\text { seus diversos usos no } \\
\text { contexto atual. }\end{array}$ & $\begin{array}{l}\begin{array}{l}\text { Metodologia } \\
\text { quantitativa, } \\
\text { etnográfica e observaçaçãa } \\
\text { participante; }\end{array} \\
\text { O “campo" de pesquisa } \\
\text { desenvolveu-ser no } \\
\text { Núcleo Fortaleza, } \\
\text { localizado em Fortaleza- } \\
\text { CE. }\end{array}$ & $\begin{array}{lll}\text { Artigo em } & \text { periódico } \\
\text { nacional. } & & \end{array}$ \\
\hline 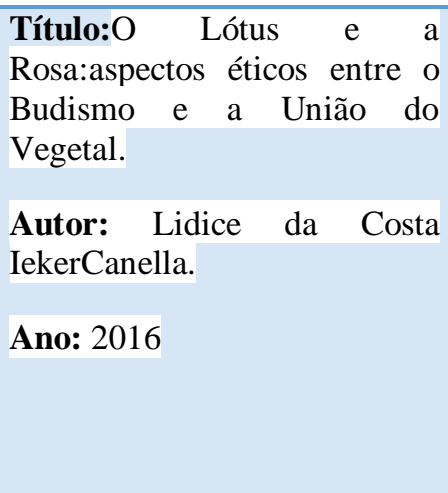 & $\begin{array}{l}\text { Dissertação - } \\
\text { Programa de } \\
\text { Pós-Graduação } \\
\text { em Ciências da } \\
\text { Religião da } \\
\text { Universidade } \\
\text { Federal da } \\
\text { Paraíba. } \\
\text { (UFPB). }\end{array}$ & $\begin{array}{l}\text { O trabalho teve como } \\
\text { objetivo traçar uma } \\
\text { comparação entre } \\
\text { duas tradições } \\
\text { religiosas distintas, o } \\
\text { Budismo e a UDV. A } \\
\text { comparação foi } \\
\text { construída através da } \\
\text { análise de códigos de } \\
\text { conduta e pela a } \\
\text { formulação de traços } \\
\text { éticos e de virtudes. }\end{array}$ & $\begin{array}{l}\text { Metodologia comparativa } \\
\text { a partir de revisão } \\
\text { literária pertinente as } \\
\text { estas duas religiões. }\end{array}$ & $\begin{array}{lll}\text { Artigo } & \text { em } & \text { periódico } \\
\text { nacional. } & & \end{array}$ \\
\hline
\end{tabular}


Um dos aspectos importantes a serem considerados, após a apresentação dessas inúmeras pesquisas, é que não se trata de caracterizar o CEBUDV, enquanto uma religião na qual os seus sócios podem ser definidos como pertencentes, em termos de uma maioria estatística, de uma classe média intelectualizada. Em nossa compreensão, este tipo de afirmação é enviesada, pois não considera a dimensão territorial, nacional e internacional do Centro, concentrandose, apenas, em pesquisas que foram conduzidas nos grandes Centros Urbanos do Brasil. Esse argumento pode ser comprovado a partir de pesquisas que observem com mais detalhes, por exemplo, o número expressivo de sócios que residemnos Centros Urbanos brasileiros e que demandam por auxílio financeiro, ou por isenção de parte dos valores de contribuição mensal que cada sócio dá ao Núcleo em que frequenta ${ }^{19}$,além das distintas profissões dos seus membros, como taxistas, vigias, enfermeiros, técnicos de enfermagem, bombeiros, policiais, professores do ensino médio, fisioterapeutas, donas de casa, cozinheiras, estudantes, administradores, vendedores, ambulantes, pedreiros, engenheiros, biólogos, advogados, promotores, juizes, entre outros. Esse é um dado significativo a ser observado.

O nosso argumento é o de que é necessária a realização de mais pesquisas, inclusive, com maiores amostragens do que aquelas praticadas até o momento, e, sobretudo, que seja considerado o caráter internacional e nacional do CEBUDV, em sua pluralidade. Contudo, para que essas pesquisas aconteçam é de fundamental importância que haja uma conduta ética dos profissionais. Pois, como observamos através dessa revisão de literatura, nem sempre foi respeitada a privacidade de assuntos e temas, que de forma "exclusiva", são desse contexto religioso. Lembramos que o CEBUDV pode ser classificado como uma religião de segredos e mistérios, na qual a transmissão dos ensinos obedece a mecanismos hierárquicos, bem como o conhecimento

19 Todos os sócios pagam uma mensalidade para os Núcleos que frequentam. Esse valor é pago para custear a manutenção das instalações (água, luz, internet, limpeza), pagamento do salário e encargos sociais dos Zeladores (um dos poucos que recebem salários para trabalharem pelo Centro). As obras, reformas e melhorias também acontecem por meio das contribuições dos sócios através da realização de promoções diversas. 
é repassado de forma lenta e gradual (WALSH NETTO, 2018). Podemos exemplificar, em comparativo, como as pesquisas desenvolvidas no candomblé devem levar em conta a preservação dos diversos segredos ritualísticos, não só para publicações acadêmicas, mas também para as pessoas que frequentem essas religiões. Ou seja, há detalhes do conhecimento e da ontologia nativa que são restritas à comunidade religiosa e são intrinsecamente ligados à composição hierárquica dessas religiões, cujos ensinos são transmitidos na pedagogia "cata folha", no candomblé, e, "devagarinho", com "cuidado com a memória", na UDV. Ou seja, tratam-se de religiões iniciáticas que prezam pelo sigilo e confiança. Desse modo, a revelação de ensinos, rituais e conteúdos doutrinários, não é o interesse das pesquisas acadêmicas (SILVA, 2000).

Essas considerações que fazemos dirigem-se aos diversos trabalhos que deram mais atenção ao conteúdo doutrinário do que à dimensão simbólica, afetiva, ontológica, social e intersubjetiva dos pesquisados. Em nosso entender, essa é uma postura investigativa que não contribui para que haja a manutenção das portas abertas para os pesquisadores. Como podemos observar ao longo dos anos dedicados a esse tema de estudo, há pesquisadores que, ao saírem do "campo", fecham as "portas" para si, assim como para os futuros pesquisadores, que precisam ter mais resistência e angariar mais esforços para conquistar a "chave", e, assim, conseguirem abrir as portas do "campo" mais uma vez. Nesse sentido, a ética é fundamental. Pois, como descreve Latour, nessa direção argumentativa, o mais importante para o pesquisador é aprender a "hablarlebien a alguien de algo para quieneso es verdaramente importante" (LATOUR, 2013, p. 58). Essa é a premissa básica, sobre a qual pensamos estar assentada a pesquisa empírica no universo acadêmico.

\section{Referências}


AGUIAR, Rosileuda Pontes. Jovens da União do Vegetal no Ceará: Práticas ritualísticas e vida comunitária no convivio com as drogas. Dissertação de Mestrado. Universidade Estadual do Ceará.2016.

ANDRADE, Afrânio Patrocínio. O Fenômeno do Chá e a Religiosidade Cabocla - Um estudo centrado na União do Vegetal. Dissertação de Mestrado. Instituto Metodista de Ensino Superior. 1995.

BARBOSA, Paulo Cesar Ribeiro. Follow-up em saúde mental de pessoas que experimentam pela primeira vez a ayahuasca em contexto religioso. Tese de Doutorado. Universidade Estadual de Campinas. 2008.

BARBOSA, Paulo Cesar Ribeiro. Psiquiatria cultural do uso ritualizado de um alucinógeno no contexto urbano: uma investigação dos estados de consciência induzidos pela ingestão da ayahuasca no santo daime e união do vegetal em moradores de São Paulo. Dissertação de Mestrado. Universidade Estadual de Campinas. 2001.

BATESON, Gregory. Steps to an Ecology of Mind. New York: Ballantine Books, 1972.

BATESON, Gregory \& BATESON, Mary. El temor de los ángeles: epistemologia de lo sagrado.Barcelona: Gedisa, 1987.

BERNARDINO-COSTA, Joaze (Org). Hoasca: Ciência, Sociedade e meio ambiente. Mercado de Letras: Campinas-SP, 2011.

BRISSAC, Sérgio Góes Telles. A Estrela do Norte Iluminando até o Sul: uma Etnografia da União do Vegetal em um Contexto Urbano. Dissertação de Mestrado. Universidade Federal do Rio de Janeiro. 1999.

CANELLA, Lídice da Costa Ieker. O Lótus e a Rosa: aspectos éticos entre o Budismo e a União do Vegetal. Dissertação de Mestrado.Universidade Federal da Paraíba. 2016.

CARVALHO, Tatiana Barbosa. Em Busca do Encontro: a demanda numinosa no contexto religioso da União do Vegetal. Dissertação de Mestrado. Pontifícia Universidade Católica. Rio de Janeiro, 2005.

GREGANICH, Jéssica. Entre a Rosa e o Beija-flor: um Estudo Antropológico de Trajetórias na União do Vegetal e no Santo Daime. Dissertação de Mestrado. Universidade Federal do Rio Grande do Sul. 2010.

HENMAN, Anthony Richard. Uso del ayahuasca en um contexto autoritario: el caso de la União do Vegetal. In: VV. AA. América Indigena, México. Vol 46, n 1, 1986. 
HÉRVIEU-LÉGER, Danièle. Le Pélerin et le Converti: lareligion em mouvement.Paris: Flammarion, 1999.

JAMES, William. As variedades da experiência religiosa. São Paulo: Cultrix, 1995.

JUNG, Carl Gustav. Memórias, Sonhos e Reflexões. Rio de Janeiro: Nova Fronteira, 2002.

LATOUR, Bruno. Investigación Sobre Los Modos de Existencia: Una Antropologia De Los Modernos. Cidade Autonóma de Buenos Aires: Paidós, 2013.

LABIGALINI, E. O uso de ayahuasca em um contexto religioso por ex-dependentes de álcool - um estudo qualitativo. Dissertação de Mestrado. Universidade Federal de São Paulo. 1998.

MELO, Rosa. Virginia. Beber na Fonte: adesão e transformação na União do Vegetal. Tese de Doutorado. Universidade de Brasília. 2010.

OTTO, Rudolf. O sagrado. Lisboa: Edições 70, 2005.

RIBEIRO, Dilma. A busca de si numa religião hoasqueira: oralidade, memória e conhecimento na União do Vegetal. Dissertação de Mestrado. Universidade Federal do Pará. 2009.

RICCIARDI, Gabriela Santos. O Uso da Ayahuasca e a Experiência de Transformação, Alivio e Cura, na União do Vegetal (UDV). Dissertação de mestrado. Universidade Federal da Bahia. 2008.

SANCHEZ, Zila Van Der Meer. As práticas religiosas atuando na recuperação de dependentes de drogas: a experiência de grupos católicos, evangélicos e espiritas. Tese de doutorado. Universidade Federal de São Paulo. 2009.

SILVA, Emanuel Luz. Jardim do Norte: experiências de sofrimento e desenvolvimento espiritual de adictos na União do Vegetal. Dissertação de Mestrado. Universidade Federal do Rio de Janeiro. 2015.

SIMMEL, Georg. A sociologia do segredo e das sociedades secretas. Revista de Ciências Humanas, Florianópolis, v. 43. n. 1, 2009.

SOUZA, Valdir Mariano. Ayahuasca, Identificando Sentidos: o uso ritual da bebida na União do Vegetal. Dissertação de Mestrado. Universidade Federal do Maranhão. 2010.

WALSH NETTO, Patrick. O exemplo na vida de quem prega: uma análise do CEBUDV a partir dos seus sócios. Tese de Doutorado. Universidade de Brasília. 2018. 
WASSON, Robert Gordon, HOFMANN, Albert y RUCK, Carl A. P. E1 camino a Eleusis: Una Solución al enigma de los mistérios. Mexico: FCE, 2013. 